\title{
Frugivory and seed dispersal of Miconia theaezans (Bonpl.) Cogniaux (Melastomataceae) by birds in a transition palm swamp - gallery forest in Central Brazil
}

\author{
Borges, MR.* and Melo, $C$.* \\ Instituto de Biologia, Universidade Federal de Uberlândia - UFU, Campus Umuarama, \\ Rua Ceará, s/n, Umuarama, CEP 38400-902, Uberlândia, MG, Brazil \\ *e-mail: mary_riborges@yahoo.com.br; celine@inbio.ufu.br
}

Received October 8, 2010 - Accepted December 17, 2010 - Distributed February 29, 2012

\begin{abstract}
The objective of this study was to evaluate potential avian dispersers of Miconia theaezans by dietary habits in the Cerrado of Central Brazil. Forty-two hours and 40 minutes of focal tree observation were conducted between 7:00 AM and 5:00 PM. For each bird species that consumed the fruit, we registered: the time they remained on the plant, the total amount of fruit they consumed, foraging tactics and strategies to consume the fruit. Five-hundred and fifty-nine units of fruit were consumed in 47 visits by seven bird species. Thraupidae was the most frequent and representative family and Tangara cayana was the main consumer. The Tachyphonus rufus had the highest rate of intake of the entire fruit, however the rates were not significantly different among the visitors. The most-used foraging tactic by all species was to consume the fruit while "perched" (95.74\% of the visits). The most commonly-used consumption strategy was to mandibulate the fruit and swallow all the contents $(65.12 \%)$. Omnivores were the predominant visitors $(71.43 \%)$ and made most of the visits (89.36\%). All visiting species could act as potential dispersers of $M$. theaezans, which demonstrates the low selectiveness of this pioneer plant towards its frugivorous.
\end{abstract}

Keywords: fruits, pioneer species, birds, cerrado.

\section{Frugivoria e dispersão de sementes de Miconia theaezans (Bonpl.) Cogniaux (Melastomataceae) por aves em uma transição Vereda - Mata de galeria no Brasil Central}

\begin{abstract}
Resumo
O objetivo deste trabalho foi avaliar, através do comportamento alimentar, as aves potencialmente dispersoras de Miconia theaezans no Cerrado do Brasil Central. Foram realizadas 42 horas e 40 minutos de observações árvore-focal, entre 07:00 e 17:00 horas. Foram registrados para cada espécie de ave consumidora de frutos: tempo de permanência na planta, total de frutos consumidos, tática de forrageio e estratégia de consumo dos frutos. Foram consumidos 559 frutos em 47 visitas, por sete espécies de aves. Thraupidae foi a família mais representativa e frequente e Tangara cayana foi o principal consumidor. A maior taxa de consumo de frutos inteiros foi encontrada para Tachyphonus rufus, porém não foi significativamente diferente entre os visitantes. A tática de forrageamento mais utilizada no consumo dos frutos de todas as espécies foi "empoleirado" (95,74\% das visitas). A estratégia de consumo mais utilizada foi mandibular o fruto e engolir todo o conteúdo $(65,12 \%)$. Houve predominância de onívoros em termos de visitantes $(71,43 \%)$ e visitas $(89,36 \%)$. Todas as espécies visitantes podem atuar como potenciais dispersoras de $M$. theaezans, demonstrando a baixa seletividade desta planta pioneira em relação aos seus frugívoros.
\end{abstract}

Palavras-chave: frutos, espécies pioneiras, aves, cerrado. 


\section{Introduction}

Seed dispersal is an important stage in the reproductive cycle of most plants because it can affect their demography and survival (Howe and Smallwood, 1982; Herrera et al., 1994). Consequently, it is a fundamental process in the maintenance and recovery of biodiversity in degraded areas (Wunderle-Junior, 1997; Hardwick et al., 2004; Trakhtenbrot et al., 2005) such as the Cerrado biome, one of the biodiversity hotspots of the planet (Myers et al., 2000).

In this biome, various plant species present fruit with attractive characteristics for animal consumption, and constitute an important food source, especially for frugivorous birds (Francisco and Galetti, 2001; Francisco and Galetti, 2002a,b; Marcondes-Machado, 2002; Melo et al., 2003; Francisco et al., 2007; Melo and Oliveira, 2009), a group that stands out when compared to other vertebrate dispersers due to its mobility and diversity of species (Scherer et al., 2007).

Pioneer plant species present characteristics (e.g. small fruit with numerous small seeds) that do not restrict their consumption (Wheelwright, 1985) and increase the chances of dispersal (Swaine and Whitmore, 1988), even if by opportunistic dispersers (Marcondes-Machado, 2002). One example is the Melastomataceae family, which is considered important for the maintenance of frugivorous diversity because most of its species present zoochoric dispersion (Stiles and Rosselli, 1993). Fruit from the Miconia genus are particularly and frequently mentioned as important food resources for frugivorous birds (Snow, 1965; Alves, 1991; Stiles and Rosselli, 1993; Galetti and Stotz, 1996; Marcondes-Machado, 2002; Manhães, 2003; Fadini and De Marco Júnior, 2004). The Miconia species fructify asynchronously in a complementary form (Snow, 1965; Maruyama et al., 2007; Borges, 2010; Leiner et al., 2010), presenting small fruit, a kind of berry, generally with numerous small seeds. This genus can be found in the Cerrado with several phytophysiognomies (Weiser and Godoy, 2001; Araújo et al., 2002; Cardoso et al., 2002; Guimarães et al., 2002; Assunção and Felfili, 2004; Gomes et al., 2004; Campos et al., 2006; Silva-Júnior and Sarmento 2009), being common in secondary vegetation (Araújo et al., 1997; Silva-Júnior and Sarmento 2009).

Miconia theaezans (Bonpl.) Cogn. is a species of shrub ( 2 to $3 \mathrm{~m}$ high), whose unripe berries are pinkish, becoming whitish-grey when ripened (personal observation). The fruit of $M$. theaezans can be a key resource for maintaining potential avian seed dispersers because it is produced throughout the entire dry season (from the end of March until September) (Borges, 2010), a period when food resources are scarce for Cerrado fauna (Develey and Peres, 2000; Batalha and Martins, 2004; Tannus et al., 2006; Silva et al., 2009).

The objective of this study was to register the species of frugivorous birds that visited the Miconia theaezans in a transition area between permanent swamps dominated by palm trees (palm swamp) and gallery forests in the Cerrado (sensu lato) and to evaluate the importance of these birds in the seed dispersal of this Melastomataceae species, based on their eating habits.

\section{Material and Methods}

\subsection{Study area}

The birds visiting Miconia theaezans were registered in the Panga Ecological Station (PES), which is a Private Natural Patrimony Reserve having an area of 409.5 ha (Cardoso and Schiavini, 2002). The PES is in Uberlândia, Minas Gerais, Brazil (19 $9^{\circ} 10^{\prime} 27^{\prime}$ 'S and $48^{\circ} 23^{\prime}$ 51' O). Until 1984, this area was used for agricultural and animal husbandry activities (Ranal, 2003). After it was transformed into a conservation area, the local vegetation recovered naturally, and today this area is considered representative of Central Brazilian Cerrado (Ranal, 2003; Cardoso et al., 2009), where various kinds of phytophysiognomies can be found, such as gallery forests, cerradão, cerrado sensu stricto, cerrado field, dirty field, humid fields and palm swamp (Schiavini and Araújo, 1989; Cardoso et al., 2009).

The climate in the region is seasonal, designated as Aw in Köppen climate classification, having two well defined seasons: a rainy season (from October to March) and a dry season (from April to September) (Rosa et al., 1991). The total precipitation in the city of Uberlândia in 2009, the year of this study, was $1313.4 \mathrm{~mm}$; the mean in the rainy season months was $174.4 \mathrm{~mm}$, and $44.5 \mathrm{~mm}$ during the dry season. The mean temperature in 2009 was $24.0^{\circ} \mathrm{C}$; the lowest mean temperature was registered in the month of June $\left(20.9^{\circ} \mathrm{C}\right)$, and the highest was registered in November $\left(25.8^{\circ} \mathrm{C}\right.$ ) (Data from the Laboratory of Climatology of UFU).

\subsection{Methods}

From the end of April to mid-May 2009, focal tree observations were carried out with four Miconia theaezans individuals to determine which species were consuming their fruit. Forty-two hours and 40 minutes of focal observation were conducted between 7:00 AM and 5:00 PM; daylight saving time was not considered.

During the observation sessions, the following information was registered: species of bird consuming the fruit, time of arrival and departure from the plant, number of units consumed, foraging tactics and consumption strategies (Melo et al., 2003; Melo and Oliveira, 2009). Taxonomic classification was in accordance with CBRO (2009). When the observed plant was visited by a group of individuals simultaneously, either monospecific or not, the number of units consumed and the time of permanence on the plant were registered only for one randomly-chosen individual (Cazetta et al., 2002). In order to determine the feeding guild of each bird, data from the literature (Table 1) and field observation were used, and the predominant diet of the species was considered in every possible case. When no data was found for the species, the predominant diet of the family was utilized (Sick, 1997).

Foraging tactics were classified according to Argelde-Oliveira et al. (1996), as "perched" or "in flight". The 
tactic was defined as "perching" when the bird remained on the plant while collecting and consuming the fruit. The tactic was considered "in flight" when the bird came to the plant, collected the fruit and landed somewhere else to consume it.

The observed birds were classified according to the consumption strategies described in Argel-de-Oliveira et al. (1996) and Marcondes-Machado (2002). The birds that swallowed the fruit whole without mandibulating it were considered "swallowers". Birds that mandibulate the fruit before ingesting it were considered "mandibulate"; they used their beaks to macerate the pulp, and afterwards swallowed either the entire pulp or just the juice, discarding the rest of the fruit with its seeds. Fruits were considered "swallowed whole" when the fruit was ingested without mandibulating, or when there was mandibulation, but the pulp and the seeds were swallowed afterwards.

\subsection{Data analysis}

The Spearman correlation was used for the number of units consumed and the time the birds remained on the Miconia theaezans. The test was processed with Systat v10.2 (Systat, 2002). The dispersal potential was calculated using the quotient of the number of units swallowed whole by the time spent by the bird on the plant (in minutes). The number of fruits swallowed whole, regardless of having been mandibulated or not, was considered to calculate the dispersal potential.

\section{Results}

Forty-seven visits by seven bird species were registered. Thraupidae was the most representative (five species) and the most frequent family (41 visits, $87.23 \%$ ). The main visiting species was Tangara cayana (28 visits, $59.57 \%$ ) (Table 1). Among the species registered, omnivorous birds predominated (five species, $71.43 \%$ ) over frugivores (two species, 28.57\%) (Table 1).

Five-hundred and fifty-nine units of M. theaezans were consumed. Tangara cayana was the main consumer (340 units, 60.52\%), and the species that consumed the least was Antilophia galeata (six units, 1.07\%). The mean time spent per visit varied from $1.25 \pm 1.06$ minutes (A. galeata) to $5.00 \pm 1.41$ minutes (Schistochlamys melanopis) (Table 2). Except for the Saltator similis, whose consumption strategy was not identified, the other species can be considered potential dispersers of $M$. theaezans due to the high number of units consumed whole per minute. The rate of whole fruit consumption varied from 2.40 (A. galeata) to 4.20 units/minutes (Tachyphonus rufus) (Table 2), and there was no significant difference between species $(\mathrm{t}=13.41, \mathrm{gl}=5, \mathrm{p}<0.01)$. The number of units consumed was correlated with the visitor's time of permanence on the plant ( $\mathrm{rs}=0.77, \mathrm{n}=47, \mathrm{p}<0.05$ ).

The "perched" foraging tactic was more common (45 visits, 95.74\%) than the "in flight" tactic. Mandibulate and swallowing was the most-used consumption strategy (364 units, $65.12 \%$ ), followed by mandibulate and disposal (121 units, 21.64\%) (Table 1).

\section{Discussion}

The main consumer and potential disperser of Miconia theaezans fruit was Tangara cayana. This Thraupidae, like other representatives of this family, mandibulates the fruit before ingestion (Gridi-Papp et al., 2004), and can swallow the whole fruit (with the seeds) or part of it (Argel-de-Oliveira et al., 1996; Sick, 1997; MarcondesMachado, 2002; Manhães, 2003). Those portions of fruit and seeds that fall on the ground during mandibulation can be used by other animals, such as ants, that can act

Table 1. Characteristics of bird visitation, with fruit consumption, on Miconia theaezans.

\begin{tabular}{|c|c|c|c|c|c|c|}
\hline \multirow{3}{*}{ Family/species } & \multirow{3}{*}{$\begin{array}{l}\text { Feeding } \\
\text { guild }\end{array}$} & \multirow{3}{*}{ Visits } & \multicolumn{4}{|c|}{ Fruit consumption } \\
\hline & & & \multirow{2}{*}{$\begin{array}{c}\text { Swallower } \\
\text { n }(\%)\end{array}$} & \multicolumn{2}{|c|}{$\begin{array}{c}\text { "Mandibulator" } \\
\text { n }(\%)\end{array}$} & \multirow{2}{*}{$\begin{array}{c}\text { Not } \\
\text { identified } \\
\text { n (\%) }\end{array}$} \\
\hline & & & & Swallows & Despises & \\
\hline \multicolumn{7}{|l|}{ TYRANNIDAE } \\
\hline Elaenia spp.*I, II, III, VI & $\mathrm{ONI}^{1,2}$ & $4(8.51)$ & $30(5.37)$ & & & \\
\hline \multicolumn{7}{|l|}{ PIPRIDAE } \\
\hline Antilophia galeata (Lichtenstein)* ${ }^{* 1 \mathrm{~V}}$ & $\mathrm{FRU}^{1,3}$ & $2(4.26)$ & $6(1.07)$ & & & \\
\hline \multicolumn{7}{|l|}{ THRAUPIDAE } \\
\hline Saltator similis (d'Orbigny \& Lafresnaye) & $\mathrm{ONI}^{1,5}$ & $1(2.13)$ & & & & $7(1.25)$ \\
\hline Schistochlamys melanopis (Latham)*v & $\mathrm{FRU}^{8}$ & $2(4.26)$ & & $33(5.90)$ & & \\
\hline Tachyphonus rufus (Boddaert)*III & $\mathrm{ONI}^{1,5,6}$ & $4(8.51)$ & & $21(3.76)$ & $61(10.91)$ & \\
\hline Tangara cayana (Linnaeus)*VI, VII & $\mathrm{ONI}^{1,4,6,7}$ & $28(59.57)$ & & $280(50.09)$ & $60(10.73)$ & \\
\hline Dacnis cayana $($ Linnaeus)*VI, VIII & $\mathrm{ONI}^{1,4,6,7}$ & $6(12.77)$ & $31(5.55)$ & $30(5.37)$ & & \\
\hline Total & & $47(100)$ & $67(11.99)$ & $364(65.12)$ & $121(21.64)$ & $7(1.25)$ \\
\hline
\end{tabular}

${ }^{1}$ Sick (1997); ${ }^{2}$ Marini and Cavalcanti (1998); ${ }^{3}$ Marini (1992); ${ }^{4}$ Argel-de-Oliveira (1999); ${ }^{5}$ Piratelli and Pereira (2002); ${ }^{6}$ Melo (2001); ${ }^{7}$ Manhães

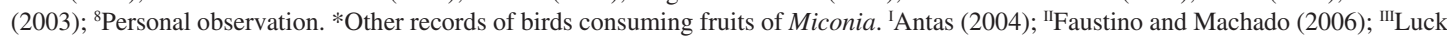
and Daily (2003); ${ }^{\mathrm{IV}}$ Guaraldo et al. (2008); ${ }^{\mathrm{V}}$ Magnuss and Sanaiotti (1987); ${ }^{\mathrm{VI}}$ Tubelis (2004); ${ }^{\mathrm{VII}}$ Parrini et al. (2008); ${ }^{\mathrm{VIII}} \mathrm{Cymerys}$ (1991). 
Table 2. Consumption rates of the Miconia theaezans fruits.

\begin{tabular}{|c|c|c|c|c|}
\hline \multirow[b]{2}{*}{ Family/species } & \multicolumn{2}{|c|}{ Fruits consumption } & \multirow{2}{*}{$\begin{array}{l}\text { Time spent on the } \\
\text { plant (minutes) } \\
\text { Mean } \pm \text { SD (n) }\end{array}$} & \multirow{2}{*}{$\begin{array}{c}\text { Consumption rate } \\
\text { (entire fruits/ } \\
\text { minutes) }\end{array}$} \\
\hline & $\begin{array}{l}\text { Total } \\
\text { n }(\%)\end{array}$ & $\begin{array}{c}\text { By visit } \\
\text { Mean } \pm \text { SD }\end{array}$ & & \\
\hline \multicolumn{5}{|l|}{ TYRANNIDAE } \\
\hline Elaenia spp. & $30(5.37)$ & $7.50 \pm 9.15$ & $2.88 \pm 2.95(4)$ & 2.93 \\
\hline \multicolumn{5}{|l|}{ PIPRIDAE } \\
\hline Antilophia galeata & $6(1.07)$ & $3.00 \pm 2.83$ & $1.25 \pm 1.06(2)$ & 2.40 \\
\hline \multicolumn{5}{|l|}{ THRAUPIDAE } \\
\hline Saltator similis & $7(1.25)$ & 7 & 1 & -- \\
\hline Schistochlamys melanopis & $33(5.90)$ & $16.50 \pm 13.44$ & $5.00 \pm 1.41(2)$ & 3.30 \\
\hline Tachyphonus rufus & $82(14.67)$ & $20.50 \pm 9.18$ & $3.88 \pm 2.25(4)$ & 4.20 \\
\hline Tangara cayana & $340(60.82)$ & $12.14 \pm 11.79$ & $3.45 \pm 2.97(28)$ & 3.94 \\
\hline Dacnis cayana & $61(10.91)$ & $10.17 \pm 5.67$ & $2.92 \pm 2.62(6)$ & 3.49 \\
\hline Total & $559(100)$ & & & \\
\hline
\end{tabular}

as secondary dispersers (Francisco and Galetti, 2002a; Christianini and Oliveira, 2009).

However, mandibulating the fruit does not eliminate the possibility of seed ingestion and dispersal because according to Levey (1987), small seeds are not easily separated from the pulp, and can be ingested after mandibulation. This was proved by Manhães (2003) when some Leandra aurea (Melastomataceae) seeds were found in the excrement of the Tangara desmaresti, a bird presenting mandibulation behavior. Therefore, the different consumption strategies used by the birds lead to a range of possibilities regarding seed ingestion and dispersal. In situations where the whole fruit is consumed, all the seeds are ingested. However, when there is mandibulation and posterior ingestion of the content, some seeds may be lost, but most are still swallowed with the fruit. The smallest, yet not null, chance of ingestion occurs when part of the fruit is discarded after mandibulation.

Except for Saltator similis, for whom the fruit consumption strategy was not identified, all species presented similar rates of consumption of the entire fruit in spite of the low number of visits compared to the Tangara cayana. Even though the Antilophia galeata consumed the whole fruit with no mandibulation and was mentioned by Marini (1992) as "highly frugivorous", it should not be considered a good disperser of this Miconia. Godoi and Takaki (2007) found that the germination of the $M$. theaezans depends considerably on the amount of light, and because the Antilophia galeata depends on a forest environment (Bagno and Marinho-Filho, 2001), most of the seeds ingested are defecated inside the gallery forest, which does not propitiate the germination of this Miconia species due to low environmental luminosity.

Pioneer species are, by definition, the first ones that colonize degraded areas, and due to this fact their main reproductive investment is to offer high numbers of seeds, increasing the chances of establishing a population in an area (Swaine and Whitmore, 1988). Considering this, the number of visits made by a certain species may not be the most important factor in the dispersal of the Miconia, but the number of units consumed and the place where they are later deposited.

The most commonly-used foraging technique (collecting the fruit while perched) is advantageous for the bird because it demands a lower energy cost and allows an increase in the rate of fruit consumption per minute (Melo et al., 2003). However, when the fruit is collected by the bird in flight, the visits are shorter and the frugivore tends to move more, which increases the chances of dispersing the seeds farther from the mother plant (Melo and Oliveira, 2009); this is favorable for plant fitness, but results in greater energy loss for the consumer (Melo and Oliveira, 2009).

According to Jordano and Schupp (2000), the amount of time visitors remained on Miconia theaezans can be considered short (less than 2 minutes). The fact that the number of units ingested by the birds is positively correlated with the time they remained indicates that the visits lasted just enough time for the bird to feed (Francisco and Galetti, 2002a), which reduces the possibility of the seeds being deposited on the mother plant.

Considering the results of this study, all the bird species that visited the Miconia theaezans can act as dispersers because they presented high rates of fruit consumption, which increases the chances of seed dispersal in places favorable to the establishment of new populations.

Acknowledgements - This study is part of the master's degree thesis of M.R. Borges. The authors are grateful to CAPES for the scholarship granted to the first author; Postgraduate Program in Ecology and Natural Resources of UFU by support; Giselle B. Alves, Liliane S.D. Carvalho and Patrísia O. Rodrigues by field assistance during the work; Dr. Rosana Romero (UFU) by plant identification; Dr. André R.T. Nascimento (UFU) and Dr. Érica Hasui (UNIFAL) by contributions to the paper. We are grateful to Willian Franklin Hanes for the English translation and to FAPEMIG for the financial support for this publication. 


\section{References}

ALVES, MAS., 1991. Dieta e táticas de forrageamento de Neothraupis fasciata em cerrado no Distrito Federal, Brasil. Ararajuba, vol. 2, p. 25-29.

ANTAS, PTZ., 2004. Pantanal: guia de aves. Rio de Janeiro: SESC.

ARAÚJO, GM., BARBOSA, AAA., ARANTES, AA. and AMARAL, AF., 2002. Composição florística de veredas no Município de Uberlândia, MG. Revista Brasileira de Botânica, vol. 25 , no. 4, p. 475-493.

ARAÚJO, GM., NUNES, JJ., ROSA, AG. and RESENDE, EJ., 1997. Estrutura comunitária de vinte áreas de cerrados residuais no município de Uberlândia, MG. Daphne, vol. 7, p. 7-14.

ARGEL-DE-OLIVEIRA, MM., 1999. Frugivoria por aves em um fragmento de floresta de restinga no estado do Espírito Santo, Brasil. Campinas: Universidade Estadual de Campinas. Tese de Doutorado em Ciências Biológicas.

ARGEL-DE-OLIVEIRA, MM., CASTIGLIONI, GDA. and SOUZA, SB., 1996. Comportamento alimentar de aves frugívoras em Trema micrantha (Ulmaceae) em duas áreas alteradas do sudeste brasileiro. Ararajuba, vol. 4, no. 1, p. 51-55.

ASSUNÇÃO, SL. and FELFILI, JM., 2004. Fitossociologia de um fragmento de cerrado sensu stricto na APA do Paranoá, DF, Brasil. Acta Botanica Brasilica, vol. 18, no. 4, p. 903-909.

BAGNO, MA. and MARINHO-FILHO, J., 2001. A avifauna do Distrito Federal: uso de ambientes abertos e florestais e ameaças. In RIBEIRO, JF., FONSECA, CEL. and SOUZA-SILVA, JC. (Eds.). Cerrado: caracterização e recuperação de Matas de Galeria. Brasília: EMBRAPA. p. 495-528.

BATALHA, MA. and MARTINS, FR., 2004. Reproductive phenology of the cerrado plant community in Emas National Park (central Brazil). Australian Journal of Botany, vol. 52, p. 149-161. http://dx.doi.org/10.1071/BT03098

BORGES, MR., 2010. Oferta de frutos e frugivoria por aves, em espécies do gênero Miconia Ruiz \& Pav. (Melastomataceae) em duas áreas do Cerrado. Uberlândia: Universidade Federal de Uberlândia. Dissertação de Mestrado em Ecologia.

CAMPOS, EP., DUARTE, TG., NERI, AV., SILVA, AF., MEIRA-NETO, JAA. and VALENTE, GE., 2006. Composição florística de um trecho de cerradão e cerrado sensu stricto e sua relação com o solo na Floresta Nacional (FLONA) de Paraopeba, MG, Brasil. Revista Árvore, vol. 30, no. 3, p. 471-479.

CARDOSO, E. and SCHIAVINI, I., 2002. Relação entre distribuição de espécies arbóreas e topografia em um gradiente florestal na Estação Ecológica do Panga (Uberlândia, MG). Revista Brasileira de Botânica, vol. 25, no. 3, p. 277-289.

CARDOSO, E., MORENO, MIC. and GUIMARÃES, AJM., 2002. Estudo fitossociológico em área de cerrado sensu stricto na Estação de Pesquisa e Desenvolvimento Ambiental Galheiro - Perdizes, MG. Caminhos da Geografia, vol. 3, no. 5, p. 30-43.

CARDOSO, E., MORENO, MIC., BRUNA, EM. and VASCONCELOS, HL., 2009. Mudanças fitofisionômicas no Cerrado: 18 anos de sucessão ecológica na Estação Ecológica do Panga, Uberlândia, MG. Caminhos da Geografia, vol. 10, no. 2, p. 254-268.

CAZETTA, E., RUBIM, P., LUNARDI, VO., FRANCISCO, MR. and GALETTI, M., 2002. Frugivoria e dispersão de sementes de
Talauma ovata (Magnoliaceae) no sudeste brasileiro. Ararajuba, vol. 10, no. 2, p. 199-206.

CHRISTIANINI, AV. and OLIVEIRA, PS., 2009. The relevance of ants as seed rescuers of a primarily bird-dispersed tree in the Neotropical cerrado savanna. Oecologia, vol. 160, no. 4, p. 735-745. PMid:19399521. http://dx.doi.org/10.1007/s00442-009-1349-2

Comitê Brasileiro de Registros Ornitológicos - CBRO, 2009. Lista de aves do Brasil. Rio de Janeiro: Sociedade Brasileira de Ornitologia. Available from: <http://www.cbro.org.br>. Access in: 05 abr. 2010.

CYMERYS, M., 1991. Can secondary forest aid in the conservation of Brazil's Atlantic Forest birds? New Haven: Tropical Resources Institute, Yale School of Forestry and Environmental Studies. Working Paper, no. 55.

DEVELEY, PF. and PERES, CA., 2000. Resource seasonality and the structure of mixed species bird flocks in a coastal Atlantic forest of southeastern Brazil. Journal of Tropical Ecology, vol. 16, p. 33-53. http://dx.doi.org/10.1017/S0266467400001255

FADINI, RF. and DE MARCO JÚNIOR, P., 2004. Interações entre aves frugívoras e plantas em um fragmento de mata atlântica de Minas Gerais. Ararajuba, vol. 12, no. 2, p. 97-103.

FAUSTINO, TC. and MACHADO, CG., 2006. Frugivoria por aves em uma área de campo rupestre na Chapada Diamantina, BA. Revista Brasileira de Ornitologia, vol. 14, no. 2, p. 137-143.

FRANCISCO, MR. and GALETTI, M., 2001. Frugivoria e dispersão de sementes de Rapanea lancifolia (Myrsinaceae) por aves numa área de cerrado do estado de São Paulo, sudeste do Brasil. Ararajuba, vol. 9, no. 1, p. 13-19. http://dx.doi.org/10.1590/ S1519-69842007000400006

-, 2002a. Aves como potenciais dispersoras de sementes de Ocotea pulchella Mart. (Lauraceae) numa área de vegetação de cerrado do sudeste brasileiro. Revista Brasileira de Botânica, vol. 25, no. 1, p. 11-17.

-, 2002b. Consumo dos frutos de Davilla rugosa (Dilleniaceae) por aves numa área de cerrado em São Carlos, Estado de São Paulo. Ararajuba, vol. 10, no. 2, p. 193-198.

FRANCISCO, MR., LUNARDI, VO. and GALETTI, M., 2007. Bird attributes, plant characteristics, and seed dispersal of Pera glabrata (Schott, 1858), (Euphorbiaceae) in a disturbed cerrado area. Brazilian Journal of Biology, vol. 67, no. 4, p. 627-634.

GALETTI, M. and STOTZ, D., 1996. Miconia hypoleuca (Melastomataceae) como espécie chave para aves frugívoras no Sudeste do Brasil. Revista Brasileira de Biologia $=$ Brazilian Journal of Biology, vol. 56, no. 2, p. 435-439.

GODOI, S. and TAKAKI, M., 2007. Seed germination in Miconia theaezans (Bonpl.) Cogniaux (Melastomataceae). Brazilian Archives of Biology and Technology, vol. 50, no. 4, p. 571-578. http://dx.doi.org/10.1590/S1516-89132007000400002

GOMES, BZ., MARTINS, FR. and TAMASHIRO, JY., 2004. Estrutura do cerradão e da transição entre cerradão e floresta paludícola num fragmento da International Paper do Brasil Ltda., em Brotas, SP. Revista Brasileira de Botânica, vol. 27, no. 2, p. 249-262.

GRIDI-PAPP, CO., GRIDI-PAPP, M. and SILVA, WR., 2004. Differential fruit consumption of two Melastomataceae by birds in Serra da Mantiqueira, southeastern Brazil. Ararajuba, vol. 12, no. 1, p. 5-10. 
GUARALDO, AC., STAGGEMEIER, VG., BROWN, TE. and GUSSONI, COA., 2008. Novas observações sobre o 'reidos-tangarás' no município de Corumbataí, São Paulo, Brasil. Cotinga, vol. 30, p. 59-60.

GUIMARÃES, AJM., ARAÚJO, GM. and CORRÊA, GF., 2002. Estrutura fitossociológica em área natural e antropizada de uma vereda em Uberlândia, MG. Acta Botanica Brasilica, vol. 16, no. 3, p. 317-329.

HARDWICK, K., HEALEY, JR., ELLIOTT, S. and BLAKESLEY, D., 2004. Research needs for restoring seasonal tropical forests in Thailand: accelerated natural regeneration. New Forest, vol. 27, p. 285-302. http://dx.doi.org/10.1023/B:NEFO.0000022228.08887.d2

HERRERA, CM., JORDANO, P., LOPEZ-SORIA, L. and AMAT, JA., 1994. Recruitment of a mast-fruiting, bird-dispersed tree: bridging frugivore activity and seedling establishment. Ecological Monographs, vol. 64, no. 3, p. 315-344. http://dx.doi. org/10.2307/2937165

HOWE, HF. and SMALLWOOD, J., 1982. Ecology of seed dispersal. Annual Review of Ecology, Evolution and Systematics, vol. 13, p. 201-228. http://dx.doi.org/10.1146/annurev.es.13.110182.001221

JORDANO, P. and SCHUPP, EW., 2000. Seed disperser effectiveness: the quantity component and patterns of seed rain for Prunus mahaleb. Ecological Monographs, vol. 70, no. 4, p. 591-615.

LEINER, NO., NASCIMENTO, ART. and MELO, C., 2010. Plant strategies for seed dispersal in tropical habitats: patterns and implications. In United Nations Educational, Scientific and Cultural Organization - UNESCO (Org.). Encyclopedia of Life Support Systems (EOLSS). Oxford: UNESCO. p. 155-170.

LEVEY, DJ., 1987. Seed size and fruiting handling techniques of avian frugivores. American Naturalist, vol. 129, no. 4, p. 471485. http://dx.doi.org/10.1086/284652

LUCK, GW. and DAILY, GC., 2003. Tropical countryside bird assemblages: richness, composition, and foraging differ by landscape context. Ecological Applications, vol. 13, no. 1, p. 235247. http://dx.doi.org/10.1890/1051-0761(2003)013[0235:TCB $\mathrm{ARC}] 2.0 . \mathrm{CO} ; 2$

MAGNUSSON, WE. and SANAIOTTI, TM., 1987. Dispersal of Miconia seeds by the rat Bolomys lasiurus. Journal of Tropical Ecology, vol. 3, p. 277-278. http://dx.doi.org/10.1017/ S0266467400002169

MANHÃES, MA., 2003. Variação sazonal da dieta e do comportamento alimentar de traupíneos (Passeriformes: Emberizidae) em Ibitipoca, Minas Gerais, Brasil. Ararajuba, vol. 11, no. 1, p. $45-55$.

MARCONDES-MACHADO, LO., 2002. Comportamento alimentar de aves em Miconia rubiginosa (Melastomataceae) em fragmento de cerrado, São Paulo. Iheringia, Série Zoológica, vol. 92 , no. 3, p. 97-100.

MARINI, MA., 1992. Foraging behavior and diet of the Helmeted Manakin. The Condor, vol. 94, p. 151-158. http://dx.doi. org/10.2307/1368804

MARINI, MA. and CAVALCANTI, RB., 1998. Frugivory by Elaenia flycatchers. Hornero, vol. 15, p. 47-50.

MARUYAMA, PK., ALVES-SILVA, E. and MELO, C., 2007. Oferta qualitativa e quantitativa de frutos em espécies ornitocóricas do gênero Miconia (Melastomataceae). Revista Brasileira de Biociências, vol. 5, p. 672-674.
MELO, C., 2001. Diurnal bird visiting of Caryocar brasiliense Camb. in Central Brazil. Revista Brasileira de Biologia=Brazilian Journal of Biology, vol. 61, no. 2, p. 311-316.

MELO, C. and OLIVEIRA, PE., 2009. Frugivory in Lacistema hasslerianum Chodat (Lacistemaceae), a gallery Forest understory treelet in Central Brazil. Brazilian Journal of Biology, vol. 69, no. 1, p. 201-207. http://dx.doi.org/10.1590/S1519-69842009000100027

MELO, C., BENTO, EC. and OLIVEIRA, PE., 2003. Frugivory and dispersal of Faramea cyanea (Rubiaceae) in cerrado woody plant formations. Brazilian Journal of Biology, vol. 63, no. 1, p. 75-82. http://dx.doi.org/10.1590/S1519-69842003000100010

MYERS, N., MITTERMEIER, RA., MITTERMEIER, CG., FONSECA, GAB. and KENT, J., 2000. Biodiversity hotspots for conservation priorities. Nature, vol. 403, p. 853-858. PMid:10706275. http://dx.doi.org/10.1038/35002501

PARRINI, R., PACHECO, JF. and HAEFELI, L., 2008. Observação de aves se alimentando dos frutos de Miconia sellowiana (Melastomataceae) na Floresta Atlântica Alto-Montana do Parque Nacional da Serra dos Órgãos e do Parque Nacional do Itatiaia, região Sudeste do Brasil. Atualidades Ornitológicas, vol. 146, p. 4-7.

PIRATELLI, A. and PEREIRA, MR., 2002. Dieta de aves na região leste de Mato Grosso do Sul, Brasil. Ararajuba, vol. 10, no. 2, p. 131-139.

RANAL, MA., 2003. Soil spore bank of ferns in a gallery forest of the Ecological Station of Panga, Uberlândia, MG, Brazil. American Fern Journal, vol. 93, no. 3, p. 97-115. http://dx.doi. org/10.1640/0002-8444(2003)093[0097:SSBOFI]2.0.CO;2

ROSA, R., LIMA, SC. and ASSUNÇÃO, WL., 1991. Abordagem preliminar das condições climáticas de Uberlândia (MG). Sociedade \& Natureza, vol. 3, p. 91-108.

SCHERER, A., MARASCHIN-SILVA, F. and BAPTISTA, LRM., 2007. Padrões de interações mutualísticas entre espécies arbóreas e aves frugívoras em uma comunidade de Restinga no Parque Estadual de Itapuã, RS, Brasil. Acta Botanica Brasilica, vol. 21, no. 1, p. 203-212. http://dx.doi.org/10.1590/S010233062007000100019

SCHIAVINI, I. and ARAUJO, GM., 1989. Considerações sobre a vegetação da Reserva Ecológica do Panga (Uberlândia). Sociedade \& Natureza, vol. 1, p. 61-66.

SICK, H., 1997. Ornitologia brasileira. Rio de Janeiro: Nova Fronteira.

SILVA, IA., CIANCIARUSO, MV. and BATALHA, MA., 2009. Dispersal modes and fruiting periods in hyperseasonal and seasonal savannas, central Brazil. Revista Brasileira de Botânica, vol. 32, no. 1, p. $155-163$.

SILVA-JÚNIOR, MC. and SARMENTO, TR., 2009. Comunidades lenhosas no cerrado sentido restrito em duas posições topográficas na Estação Ecológica do Jardim Botânico de Brasília, DF, Brasil. Rodriguésia, vol. 60, no. 20, p. 277-294.

SNOW, DW., 1965. A possible selective factor in the evolution of fruiting seasons in tropical forest. Oikos, vol. 15, no. 2, p. $274-$ 281. http://dx.doi.org/10.2307/3565124

STILES, FG. and ROSSELLI, L., 1993. Consumption of fruits of the Melastomataceae by birds: how diffuse is coevolution? Vegetatio, vol. 107-108, no. 1, p. 57-73. 
SWAINE, MD. and WHITMORE, TC., 1988. On the definition of ecological species groups in tropical rain forest. Vegetatio, vol. 75 , p. 81-86.

Systat Software Inc., 2002. Version 10.2. Copyright SYSTAT Software Inc.

TANNUS, JLS., ASSIS, MA. and MORELLATO, LP., 2006. Fenologia reprodutiva em campo sujo e campo úmido numa área de Cerrado no sudeste do Brasil, Itirapina, SP. Biota Neotropica. Available from: <http://www.biotaneotropica.org.br/v6n3/pt/do wnload?article+bn02806032006+item>. Access in: 12 jan. 2010.

TRAKHTENBROT, A., NATHAN, R., PERRY, G. and RICHARDSON, DM., 2005. The importance of longdistance dispersal in biodiversity conservation. Diversity and Distributions, vol. 11, p. 173-181. http://dx.doi.org/10.1111/j.13669516.2005.00156.x
TUBELIS, DP., 2004. Species composition and seasonal occurrence of mixed-species flocks of forest birds in savannas in central cerrado, Brazil. Ararajuba, vol. 12, no. 2, p. 105-111.

WEISER, VL. and GODOY, SAP., 2001. Florística em um hectare de cerrado stricto sensu na ARIE - Cerrado Pé-de-gigante, Santa Rita do Passa Quatro, SP. Acta Botanica Brasilica, vol. 15, no. 2, p. 201-212.

WHEELWRIGHT, NT., 1985. Fruit size, gape width, and the diets of fruit-eating birds. Ecology, vol. 66, no. 3, p. 808-818.

WUNDERLE-JUNIOR., JM., 1997. The role of animal seed dispersal in accelerating native forest regeneration on degraded tropical lands. Forest Ecology and Management, vol. 99, p. 223235. http://dx.doi.org/10.1016/S0378-1127(97)00208-9 
